Article

\title{
Terpenoids from the Deep-Sea-Derived Fungus Penicillium thomii YPGA3 and Their Bioactivities
}

\author{
Zhongbin Cheng ${ }^{1,4, *}$, Wan Liu ${ }^{1}$, Runzhu Fan ${ }^{3}$, Shouye Han ${ }^{1}$, Yuanli Li ${ }^{1}$, Xiaoyun Cui ${ }^{1}$, \\ Jia Zhang ${ }^{1}$, Yinan Wu ${ }^{1}$, Xin Lv ${ }^{1}$, Yun Zhang ${ }^{1}$, Zhuhua Luo ${ }^{2}$, Siti Aisyah Alias ${ }^{5}$, Wei Xu ${ }^{2, *}$ \\ and Qin $\mathrm{Li}^{1,4, *}$ \\ 1 School of Pharmacy, Henan University, Kaifeng 475004, China; 18737806806@163.com (W.L.); \\ hanshouye123@163.com (S.H.); ly13287439993@163.com (Y.L.); cxy521bjt@163.com (X.C.); \\ z919395@126.com (J.Z.); w1287457895@163.com (Y.W.); 15225826138@163.com (X.L); \\ zy190831@163.com (Y.Z.) \\ 2 Key Laboratory of Marine Biogenetic Resources, Third Institute of Oceanography, Ministry of Natural \\ Resources, Xiamen 361005, China; luozhuhua@tio.org.cn \\ 3 School of Pharmaceutical Sciences, Sun Yat-sen University, Guangzhou 510006, China; \\ fanrzh@mail2.sysu.edu.cn \\ 4 Eucommia Ulmoides Cultivation and Utilization of Henan Engineering Laboratory, Kaifeng 475004, China \\ 5 Institute of Ocean and Earth Science (IOES), C308, Institute of Postgraduate Studies Building, University of \\ Malaya, Kuala Lumpur 50603, Malaysia; siti.alias@gmail.con \\ * Correspondence: czb360@126.com (Z.C.); xuwei@tio.org.cn (W.X.); liqin6006@163.com (Q.L.); \\ Tel.: +86-371-2388-3849 (Q.L.)
}

Received: 27 January 2020; Accepted: 12 March 2020; Published: 16 March 2020

\begin{abstract}
A chemical study of the ethyl acetate (EtOAc) extract from the deep-sea-derived fungus Penicillium thomii YPGA3 led to the isolation of a new austalide meroterpenoid (1) and seven known analogues (2-8), two new labdane-type diterpenoids (9 and 10) and a known derivative (11). The structures of new compounds 1, 9, and 10 were determined by comprehensive analyses via nuclear magnetic resonance (NMR) and mass spectroscopy (MS) data. The absolute configurations of $\mathbf{1}, \mathbf{9}$, and 10 were determined by comparisons of experimental electronic circular dichroism (ECD) with the calculated ECD spectra. Compound 1 represented the third example of austalides bearing a hydroxyl group at C-5 instead of the conserved methoxy in other known analogues. To our knowledge, diterpenoids belonging to the labdane-type were discovered from species of Penicillium for the first time. Compound 1 showed cytotoxicity toward MDA-MB-468 cells with an $\mathrm{IC}_{50}$ value of $38.9 \mu \mathrm{M}$. Compounds 2 and 11 exhibited inhibition against $\alpha$-glucosidase with $\mathrm{IC}_{50}$ values of 910 and $525 \mu \mathrm{M}$, respectively, being more active than the positive control acarbose (1.33 $\mathrm{mM})$.
\end{abstract}

Keywords: Penicillium thomii YPGA3; deep-sea-derived fungus; austalide meroterpenoid; labdane-type diterpenoid; bioactivities

\section{Introduction}

Austalides are a class of natural meroterpenoids with attractive scaffolds. Previous biosynthetic studies revealed that they are biosynthesized by cyclization and oxidative modification of 6-[(2E, 6E)farnesyl]-5,7-dihydroxy-4-methylphthalide [1]. These meroterpenoids were mainly produced by the species of the fungal genera Aspergillus and Penicillium, especially those from marine environments. Since austalides A-E were first reported in 1981, a total of 36 analogues have been identified [2-11]. The structural variations of austalides are attributed to oxidation occurring at C-13, C-14, C-17, and the isopropyl (C-15, C-25, C-26) to generate alcohol, isopropenyl, lactone, ester, or ether functionalities. Some of the analogues exhibited significant bioactivities, such as cytotoxicity $[6,10]$, 
antibacterial activity [7], anti-influenza A virus (H1N1) activity [8], endo-1,3-D-glucanase inhibition [9], and osteoclast differentiation inhibitory effects [11].

In our efforts to search for new or bioactive molecules from deep-sea-derived Penicillium or Aspergillus strains [12-15], chemical examination of Penicillium thomii YPGA3 afforded a new austalide meroterpenoid (1) and seven known analogues (2-8) (Figure 1). Compound 1 represented the third example of austalides bearing a phenol hydroxy at C-5 instead of the conserved methoxy in other known analogues. Additionally, two new labdane-type diterpenoids (9 and 10) and a known analogue (11) were also obtained (Figure 1). The labdane-type diterpenoids are mainly produced by plants and are rarely found in fungus. To our knowledge, diterpenoids belonging to the labdane-type were discovered from species of Penicillium for the first time. All compounds were evaluated for their inhibitions against $\alpha$-glucosidase and NO (nitric oxide) production in lipopolysaccharide (LPS)-activated RAW 264.7 macrophages, and cytotoxicity toward two types of human breast carcinoma cells. Herein, the isolation, structural elucidation, and the bioactivity of compounds 1-11 are described.
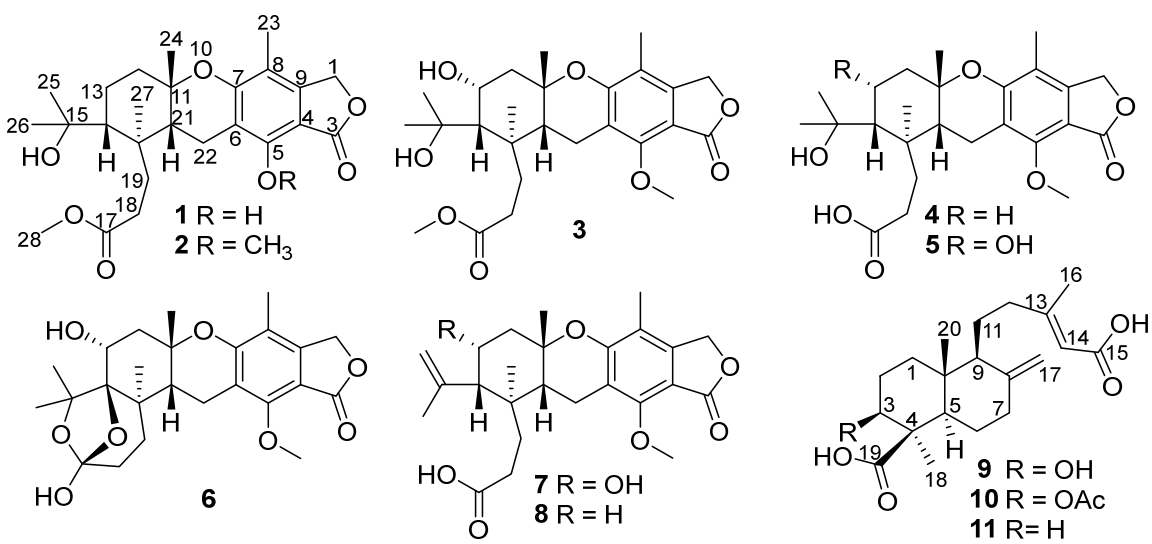

Figure 1. Structures of compounds 1-11 from Penicillium thomii YPGA3.

\section{Results}

Compound 1 had a molecular formula of $\mathrm{C}_{25} \mathrm{H}_{34} \mathrm{O}_{7}$, as established by the high-resolution electrospray ionization mass spectroscopy (HRESIMS) (469.2202 [M $+\mathrm{Na}]^{+}$, calcd. for 469.2197) (see Figure S34 in the Supplementary Materials), requiring nine degrees of unsaturation. The ${ }^{1} \mathrm{H}$ nuclear magnetic resonance (NMR) spectrum exhibited signals for five methyl singlets $\left(\delta_{\mathrm{H}} 2.02,1.28\right.$, $1.21 \times 2,0.71)$, a methoxy $\left(\delta_{\mathrm{H}} 3.67\right)$, an oxygenated methylene $\left(\delta_{\mathrm{H}} 5.22\right)$, and a series of alkyl protons (see Figure S1). The ${ }^{13} \mathrm{C}$ NMR and the heteronuclear single-quantum coherence (HSQC) spectra exhibited 25 carbon resonances attributable to a benzene ring $(\delta c 160.8,153.8,145.4,112.3,103.0,111.2)$, five methyls $(\delta c 33.2,28.2,27.7,19.4,10.6)$, a methoxy ( $\delta c 52.0)$, six methylenes $(\delta c 70.6,40.5,22.6$, $30.1,34.9,18.4)$ including an oxygenated one, two methines $(\delta c 41.5,52.1)$, two ester carbons $(\delta c$ $174.2,177.0)$, one $\mathrm{sp}^{3}$ quaternary carbon $(\delta \mathrm{c} 42.8)$, and two oxygenated carbons $(\delta \mathrm{c} 78.2,75.8)$ (see Figures S2 and S3). As six degrees of unsaturation were accounted for by the benzene ring and two carbonyl carbons, the remaining three degrees of unsaturation required that compound 1 contained three additional rings. The aforementioned information was very similar to that of austalide P (2) [6], a co-isolated analogue first isolated from a sponge-associated fungus Aspergillus sp., with the only difference owing to the absence of the aromatic methoxy group $\left(\delta_{\mathrm{H}} 4.04, \delta_{\mathrm{C}} 62.2\right)$ in 2 . This indicated that $\mathbf{1}$ was the 5 -demethoxylated derivative of $\mathbf{2}$. The structure of $\mathbf{1}$ was further certified as correct by detailed interpretation of 2D NMR data (Figure 2). The relative configuration of 1 was assigned by a nuclear Overhauser effect spectroscopy (NOESY) experiment (Figure 3). The NOE correlations of $\mathrm{H}-21\left(\delta_{\mathrm{H}} 1.68\right) / \mathrm{H}_{3}-24\left(\delta_{\mathrm{H}} 1.21\right), \mathrm{H}-14\left(\delta_{\mathrm{H}} 1.55\right), \mathrm{H}_{3}-24 / \mathrm{H}-22 \beta\left(\delta_{\mathrm{H}} 2.69\right)$, and $\mathrm{H}_{3}-27\left(\delta_{\mathrm{H}} 0.71\right) / \mathrm{H}-22 \alpha$ $\left(\delta_{\mathrm{H}}\right.$ 2.94) clarified the same orientation of $\mathrm{H}_{3}-24, \mathrm{H}-21$, and $\mathrm{H}-14$, while $\mathrm{H}_{3}-27$ was in the opposite orientation. Thus, the relative configuration of 1 was assigned as $11 S^{*}, 14 R^{*}, 20 S^{*}$, and $21 R^{*}$. In order 
to resolve its absolute configuration, the theoretical electronic circular dichroism (ECD) data of $11 S$, $14 R, 20 S, 21 R-1$ were calculated by the time-dependent density-functional theory (TDDFT) method and showed an ECD curve with Cotton effects at $265(-), 227(+)$, and $214(-) \mathrm{nm}$, which were in good agreement with the experimental cotton effects at $264(-), 229(+)$, and $212(-)$ nm (Figure 4), suggesting that compound $\mathbf{1}$ has the $11 S, 14 R, 20 S, 21 R$ configuration. Compound $\mathbf{1}$ was given the trivial name austalide $Y$ and represented the third example of an austalide meroterpenoid without the 5-methoxy group.
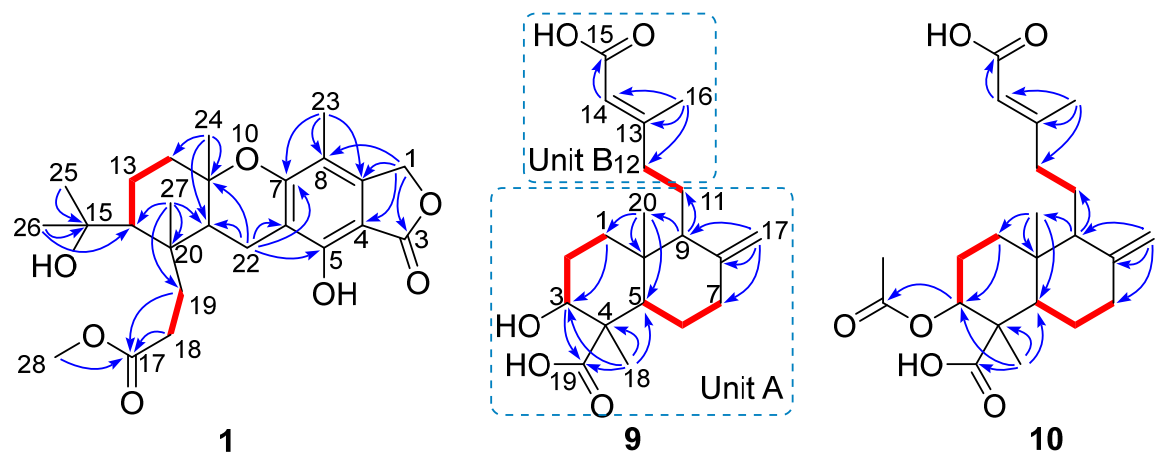

Figure 2. Key correlation spectroscopy (COSY, - ) and heteronuclear multiple-bond correlations $(\mathrm{HMBC}, \longrightarrow$ ) of compounds 1, 9, and $\mathbf{1 0 .}$
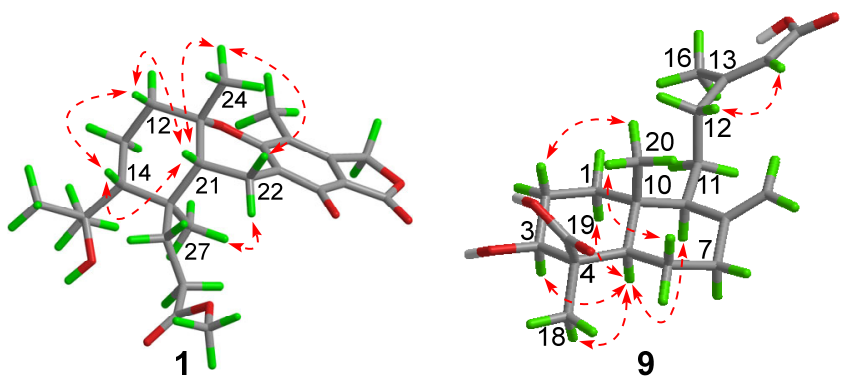

Figure 3. Key nuclear Overhauser effect spectroscopy (NOESY) correlations ( $\leftrightarrow$ ) of compounds 1 and 9.

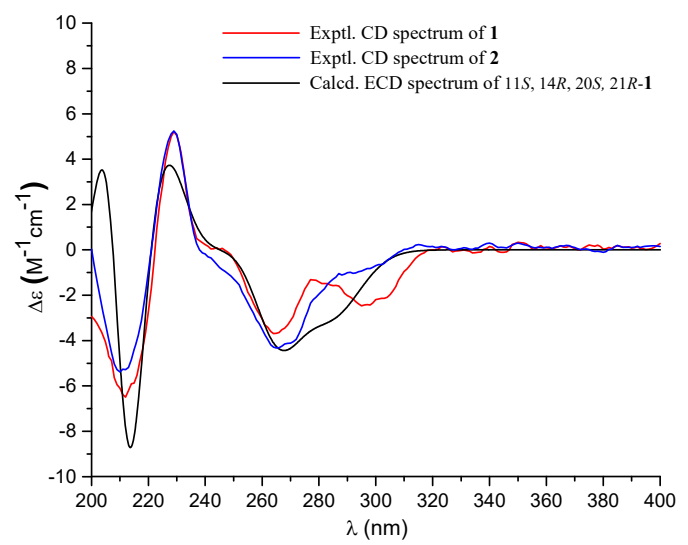

Figure 4. Experimental electronic circular dichroism (ECD) spectra (200-400 nm) of compounds 1 and 2 in methanol and the calculated ECD spectrum of $11 S, 14 R, 20 S, 21 R-\mathbf{1}$ at the B3LYP/6-31+G $(\mathrm{d}, \mathrm{p})$ level in methanol.

Compound 9 was isolated as a colorless oil with the molecular formula of $\mathrm{C}_{20} \mathrm{H}_{30} \mathrm{O}_{5}$ as determined by the HRESIMS at $m / z 373.1991[\mathrm{M}+\mathrm{Na}]^{+}$(calcd. 373.1985), requiring six degrees of unsaturation. 
The ${ }^{1} \mathrm{H}$ NMR spectrum exhibited signals for an olefinic methyl $\left(\delta_{\mathrm{H}} 2.13\right)$, two methyl singlets $\left(\delta_{\mathrm{H}} 1.38\right.$ and 0.69$)$, an olefinic methylene $\left(\delta_{\mathrm{H}} 4.56,4.90\right)$, an oxygenated proton $\left(\delta_{\mathrm{H}} 3.18\right)$, and several aliphatic protons. The ${ }^{13} \mathrm{C}$ NMR spectra exhibited 20 carbon resonances, which were classified by an HSQC experiment as three methyls $\left(\delta_{C} 24.8,18.9,13.5\right)$, six sp ${ }^{3}$ methylenes $\left(\delta_{C} 40.7,39.6,38.7,29.7,27.2,23.0\right)$, three methines $\left(\delta_{C} 79.0,56.5 \times 2\right)$ including one oxygenated methine, two $\mathrm{sp}^{3}$ quaternary carbons $\left(\delta_{C}\right.$ $50.3,41.0)$, two carboxylic acid groups $\left(\delta_{C} 170.4,180.5\right)$, and two double bonds $\left(\delta_{C} 161.7,149.0,107.3\right.$, 116.9). As four of the six degrees of unsaturation were covered by two carboxylic acid groups and two double bonds, the remaining two degrees of unsaturation required that 9 was bicyclic. The gross structure was further established by detailed analyses of the 2D NMR data (Figure 2). The correlation spectroscopy (COSY) relationships from $\mathrm{H}_{2}-1$ to $\mathrm{H}-3$ and $\mathrm{H}-5$ to $\mathrm{H}_{2}-7$ coupled with the heteronuclear multiple-bond correlations (HMBCs) of $\mathrm{H}_{3}-20\left(\delta_{\mathrm{H}} 0.69\right)$ to $\mathrm{C}-1\left(\delta_{\mathrm{C}} 38.7\right), \mathrm{C}-5\left(\delta_{\mathrm{C}} 56.5\right), \mathrm{C}-10\left(\delta_{\mathrm{C}} 41.0\right)$, $\mathrm{H}_{3}-18\left(\delta_{\mathrm{H}} 1.38\right)$ to $\mathrm{C}-3\left(\delta_{\mathrm{C}} 79.0\right), \mathrm{C}-4\left(\delta_{\mathrm{C}} 50.3\right), \mathrm{C}-5, \mathrm{C}-19\left(\delta_{\mathrm{C}} 180.5\right)$, the olefinic methylene protons $\mathrm{H}_{2}-17\left(\delta_{\mathrm{H}} 4.56,4.90\right)$ to $\mathrm{C}-7\left(\delta_{\mathrm{C}} 39.6\right), \mathrm{C}-8\left(\delta_{\mathrm{C}} 149.0\right), \mathrm{C}-9\left(\delta_{\mathrm{C}} 56.5\right)$, and H-9 $\left(\delta_{\mathrm{H}} 1.61\right)$ to $\mathrm{C}-11\left(\delta_{\mathrm{C}} 23.0\right)$, $\mathrm{C}-20\left(\delta_{\mathrm{C}} 13.5\right)$ established a bicyclic unit (unit A). Additional HMBCs from $\mathrm{H}_{3}-16\left(\delta_{\mathrm{H}} 2.13\right)$ to $\mathrm{C}-12\left(\delta_{\mathrm{C}}\right.$ 40.7), C-13 $\left(\delta_{\mathrm{C}} 161.7\right), \mathrm{C}-14\left(\delta_{\mathrm{C}} 116.9\right)$, and H-14 $\left(\delta_{\mathrm{H}} 5.61\right)$ to $\mathrm{C}-15\left(\delta_{\mathrm{H}} 170.4\right)$ established a senecioic acid moiety (unit B), which was linked to unit $\mathrm{A}$ at $\mathrm{C}-11$ by the ${ }^{1} \mathrm{H}-{ }^{1} \mathrm{H}$ COSY relationship between $\mathrm{H}_{2}-11$ and $\mathrm{H}_{2}-12$. Thus, the gross structure of 9 was established as depicted. The relative configuration of 9 was determined by an NOESY experiment (Figure 3 ) and coupling constants. The coupling constants of $J_{\mathrm{H}-3 / \mathrm{H}-2 \alpha}(4.4 \mathrm{~Hz})$ and $J_{\mathrm{H}-3 / \mathrm{H}-2 \beta}(12.1 \mathrm{~Hz})$ suggested that $\mathrm{OH}-3$ was $\beta$-orientated. The NOE correlations of $\mathrm{H}-5$ with $\mathrm{H}-3, \mathrm{H}-9\left(\delta_{\mathrm{H}} 1.61\right), \mathrm{H}_{3}-18\left(\delta_{\mathrm{H}} 1.38\right), \mathrm{H}_{3}-18$ with $\mathrm{H}-6 \alpha\left(\delta_{\mathrm{H}} 2.03\right)$, and $\mathrm{H}_{3}-20\left(\delta_{\mathrm{H}} 0.69\right)$ with $\mathrm{H}-6 \beta\left(\delta_{\mathrm{H}} 1.93\right)$ indicated that $\mathrm{H}-3, \mathrm{H}-5$, and $\mathrm{H}-9$ were $\alpha$-orientated, while $\mathrm{H}_{3}-20$ was $\beta$-orientated. The NOE correlation between $\mathrm{H}-14$ and $\mathrm{H}_{2}-12\left(\delta_{\mathrm{H}} 2.30,2.02\right)$ was indicative of an $E$ configuration of the double bond $\Delta^{13}$. Comparison of the experimental ECD data with those of the calculated ECD data at the B3LYP/6-31+G(d,p) level for 3S, 4R, 5R, 9S, 10R-9 allowed the assignment of the 3S, 4R, 5R, 9S, $10 R$ configuration for 9 (Figure 5). As the structure of 9 was 3-hydroxylated derivative of agathic acid (10) [16], it was named 3 $\beta$-hydroxy-agathic acid.

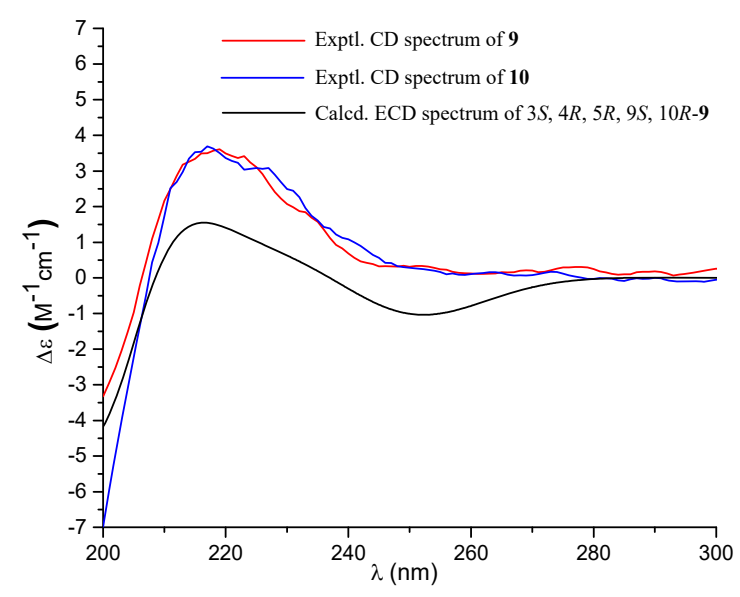

Figure 5. Experimental ECD spectra (200-300 nm) of 9 and 10 in methanol and the calculated ECD spectrum of $3 S, 4 R, 5 R, 9 S, 10 R-9$ at the B3LYP/6-31+G(d,p) level in methanol.

Compound 10 had a molecular formula of $\mathrm{C}_{22} \mathrm{H}_{32} \mathrm{O}_{6}$, as determined by the HRESIMS at $\mathrm{m} / \mathrm{z}$ 415.2096 $[\mathrm{M}+\mathrm{H}]^{+}$(calcd. 415.2091), requiring seven degrees of unsaturation. The NMR data of $\mathbf{1 0}$ were similar to those of 9 with the obvious distinction due to the presence of an acetyl group $\left(\delta_{\mathrm{H}}\right.$ $\left.2.04, \delta_{\mathrm{C}} 172.8\right)$, suggesting that 10 was an acetylated derivative of $\mathbf{9}$. The downfield-shifted $\mathrm{H}-3\left(\delta_{\mathrm{H}}\right.$ 4.55) showed an HMBC with the acetyl carbonyl carbon $\left(\delta_{C} 172.8\right)$, locating the acetyl group at C-3 (Figure 2). The relative configuration of $\mathbf{1 0}$ was determined to be the same as that of $\mathbf{9}$ based on their similar NOESY data. The structure of $\mathbf{1 0}$ was determined as depicted and is a C-3 epimer of a known analogue mumic acid A [17]. The similar specific rotations and circular dichroism (CD) spectra of 9 
and $\mathbf{1 0}$ confirmed the same absolute configuration of both $\mathbf{9}$ and $\mathbf{1 0}$ (Figure 5), and compound $\mathbf{1 0}$ was named $3 \beta$-acetoxy-agathic acid.

In addition, eight additional known compounds were identical to austalide $\mathrm{P}$ (2) [6], austalide $\mathrm{H}$ (3) [5], austalide P acid (4) [9], austalide H acid (5) [9], 17-O-demethylaustalide B (6) [9], austalide Q acid (7) [9], 13-deoxyaustalide $Q$ acid (8) [9], and agathic acid (10) [16] based on comparisons of their NMR data and specific rotations with those reported in the literature. Furthermore, the ${ }^{13} \mathrm{C}$ NMR data of austalide $\mathrm{H}(3)$ and ${ }^{13} \mathrm{C}$ NMR data of compounds 3,4 , and 7 in methanol- $d_{6}$ were reported for the first time.

All compounds were screened for their inhibitory activities against $\alpha$-glucosidase at the initial concentration of $1 \mathrm{mM}$. Compounds 2 and $\mathbf{1 1}$ exhibited inhibition by more than $50 \%$ and were further evaluated to calculate the $\mathrm{IC}_{50}$ values. The results showed that compounds $\mathbf{2}$ and $\mathbf{1 1}$ inhibited $\alpha$-glucosidase with $\mathrm{IC}_{50}$ values of $910 \pm 4$ and $525 \pm 2 \mu \mathrm{M}$, being more active than the positive control acarbose $(1.33 \mathrm{mM})$. Other compounds, on the other hand, showed inhibition less than $40 \%$ at the concentration of $1 \mathrm{mM}$. As for the labdane-type diterpenoids 9-11, the introduction of hydroxy and acetoxy groups at C-3 may lead to a sharp decrease in activity, since compounds $\mathbf{9}$ and $\mathbf{1 0}$ showed low inhibition when compared with that of $\mathbf{1 1 .}$

The isolated compounds were also evaluated for their inhibitory effects against NO production in LPS-activated RAW 264.7 macrophages at the concentration of $50 \mu \mathrm{M}$ following the same procedures in our previous study [10]. The cell viability was further determined by the MTT assay to evaluate whether the inhibition on NO production was owing to the cytotoxicity. As results (see Table S1 in the Supplementary Materials), compounds 1, 2, and 10, possessing inhibition rates of more than $50 \%$ on NO production, showed obvious cytotoxic effects, which suggested that the inhibitory effects of NO production were due to the cytotoxicity. All compounds were further evaluated for their cytotoxicity toward two types of human breast carcinoma cells (MCF-7, MDA-MB-468) [13], and the results showed that only compound 1 showed a weak inhibitory effect toward MDA-MB-468 cells with an $\mathrm{IC}_{50}$ value of $38.9 \pm 1.83 \mu \mathrm{M}$.

\section{Experimental Section}

\subsection{General Experimental Procedure}

Specific rotations were recorded by an SGW ${ }^{\circledR}-1$ automatic polarimeter (Shanghai Jing Ke Industrial Co., Ltd., Shanghai, China). The NMR spectra were measured on a Bruker Avance III HD-400 spectrometer (Bruker, Fällanden, Switzerland). HRESIMS spectra were obtained on a Waters Xevo G2 Q-TOF spectrometer (Waters Corporation, Milford, MA, USA). Semi-preparative high-performance liquid chromatography (HPLC) was undertaken on a Shimadzu LC-6AD pump (Shimadzu Co., Kyoto, Japan) using a UV detector, and a YMC-Pack ODS-A HPLC column (semipreparative, $250 \times 10 \mathrm{~mm}$, S-5 $\mu \mathrm{m}, 12 \mathrm{~nm}$, YMC Co., Ltd, Kyoto, Japan) was used for separation.

\subsection{Fungal Strain and Identification}

Fungus YPGA3 was isolated from deep sea water at a depth of $4500 \mathrm{~m}$ in the Yap Trench (West Pacific Ocean). The strain was identified as Penicillium thomii based on microscopic examination and by internal transcribed spacer (ITS) sequencing. The ITS sequence was deposited in GenBank (http://www.ncbi.nlm.nih.gov) with accession number MG835903. The strain YPGA3 (MCCC 3A01052) was deposited at the Marine Culture Collection of China.

\subsection{Fermentation}

The fermentation was carried out in 30 Fernbach flasks $(500 \mathrm{~mL})$, each containing $70 \mathrm{~g}$ of rice. Artificial seawater $(90 \mathrm{~mL})$ was added to each flask, and the contents were soaked for three hours before autoclaving at $15 \mathrm{psi}$ for $30 \mathrm{~min}$. After cooling to room temperature, each flask was inoculated with $3.0 \mathrm{~mL}$ of the spore inoculum and incubated at room temperature for 30 days. 


\subsection{Extraction and Isolation}

The fermented materials were extracted with ethyl acetate (EtOAc) $(3 \times 5000 \mathrm{~mL})$ in an ultrasonic bath at $30^{\circ} \mathrm{C}$ for $20 \mathrm{~min}$. After evaporation under vacuum, the EtOAc extract (3.1g) was subjected to ODS silica gel column chromatography (CC) eluting with $\mathrm{MeOH} / \mathrm{H}_{2} \mathrm{O}(20: 80 \rightarrow 100: 0)$ to afford ten fractions (F1-F10). F5 was further chromatographed over C-18 silica gel CC eluted with $\mathrm{MeOH} / \mathrm{H}_{2} \mathrm{O}$ (65:35) to afford seven subfractions (F5a-F5g). F5d was further purified by HPLC on a semi-preparative YMC-pack ODS-A column using $\mathrm{CH}_{3} \mathrm{CN} / \mathrm{H}_{2} \mathrm{O}(61: 39,3 \mathrm{~mL} / \mathrm{min})$ to afford 5 ( $\left.31 \mathrm{mg}, \mathrm{t}_{R} 40 \mathrm{~min}\right)$. F6 was further chromatographed over ODS silica gel CC eluted with $\mathrm{MeOH} / \mathrm{H}_{2} \mathrm{O}(20: 80 \rightarrow 100: 0)$ to afford fourteen subfractions (F6a-F6n). F6d was separated by $\mathrm{HPLC} \mathrm{CH}_{3} \mathrm{CN} / \mathrm{H}_{2} \mathrm{O}(54: 46,3 \mathrm{~mL} / \mathrm{min}$ ) to yield $3\left(14 \mathrm{mg}, \mathrm{t}_{\mathrm{R}} 19.9 \mathrm{~min}\right)$. Purification of F6e by HPLC using $\mathrm{CH}_{3} \mathrm{CN} / \mathrm{H}_{2} \mathrm{O}(54: 46,3 \mathrm{~mL} / \mathrm{min}$ ) gave 7 (10 $\mathrm{mg}$, $\left.\mathrm{t}_{\mathrm{R}} 21.9 \mathrm{~min}\right)$. F6h was purified by HPLC using $\mathrm{CH}_{3} \mathrm{CN} / \mathrm{H}_{2} \mathrm{O}(52: 48,3 \mathrm{~mL} / \mathrm{min})$ to give 9 ( $3 \mathrm{mg}$, $\left.\mathrm{t}_{R} 23.9 \mathrm{~min}\right)$. F6i was purified by $\mathrm{HPLC}$ using $\mathrm{CH}_{3} \mathrm{CN} / \mathrm{H}_{2} \mathrm{O}(53: 47,3 \mathrm{~mL} / \mathrm{min})$ to afford $4\left(5 \mathrm{mg}\right.$, $\mathrm{t}_{R}$ $49.6 \mathrm{~min})$ and $10\left(2 \mathrm{mg}, \mathrm{t}_{R} 53.6 \mathrm{~min}\right)$. F6j was purified by $\mathrm{HPLC}$ using $\mathrm{CH}_{3} \mathrm{CN} / \mathrm{H}_{2} \mathrm{O}(50: 50,3 \mathrm{~mL} / \mathrm{min})$ to afford $6\left(2 \mathrm{mg}, \mathrm{t}_{\mathrm{R}} 22.5 \mathrm{~min}\right)$. F6k was purified by $\mathrm{HPLC}$ using $\mathrm{CH}_{3} \mathrm{CN} / \mathrm{H}_{2} \mathrm{O}(65: 35,3 \mathrm{~mL} / \mathrm{min})$ to afford $1\left(1 \mathrm{mg}, \mathrm{t}_{R} 36.2 \mathrm{~min}\right)$ and $2\left(6 \mathrm{mg}, \mathrm{t}_{R} 39.0 \mathrm{~min}\right)$. F6l was purified by $\mathrm{HPLC}$ using $\mathrm{CH}_{3} \mathrm{CN} / \mathrm{H}_{2} \mathrm{O}$ $(68: 32,3 \mathrm{~mL} / \mathrm{min})$ to afford $\mathbf{1 1}\left(20 \mathrm{mg}, \mathrm{t}_{R} 24.4 \mathrm{~min}\right)$. F6m was purified by $\mathrm{HPLC}$ using $\mathrm{CH}_{3} \mathrm{CN} / \mathrm{H}_{2} \mathrm{O}$ (70:30, $3 \mathrm{~mL} / \mathrm{min})$ to afford $8\left(1.5 \mathrm{mg}, \mathrm{t}_{R} 48.9 \mathrm{~min}\right)$.

Austalide Y (1): colorless oil; $[\alpha]_{\mathrm{D}}^{25}-33(c 0.05, \mathrm{MeOH}) ; \mathrm{UV}(\mathrm{MeOH}) \lambda_{\max } 222,270 \mathrm{~nm}$; ECD (c 2.24 $\left.\times 10^{-4} \mathrm{M}, \mathrm{MeOH}\right) \lambda_{\max }(\Delta \varepsilon) 264(-3.69), 229(+5.21), 212(-6.49) ;{ }^{1} \mathrm{H}$ and ${ }^{13} \mathrm{C}$ NMR data, see Table $1 ;$ HRESIMS $m / z 469.2202[\mathrm{M}+\mathrm{Na}]^{+}$(calcd. for $\mathrm{C}_{25} \mathrm{H}_{34} \mathrm{O}_{7} \mathrm{Na}^{+}, 469.2197$ ).

Table 1. Nuclear magnetic resonance (NMR) data of 1, 3, 4, and 7 in Methanol- $d_{4}{ }^{\text {a }}$ ( $\delta$ in ppm).

\begin{tabular}{|c|c|c|c|c|c|}
\hline & & 1 & 3 & 4 & 7 \\
\hline No. & $\delta_{H}$ (mult., $J$ in $\mathrm{Hz}$ ) & $\delta_{C}$ & $\delta_{C}$ & $\delta_{C}$ & $\delta_{C}$ \\
\hline $1, \mathrm{CH}_{2}$ & $5.22, \mathrm{~s}$ & 70.6 & 69.8 & 69.8 & 69.8 \\
\hline $3, C^{2}$ & & 174.2 & 171.9 & 171.9 & 171.8 \\
\hline $4, \mathrm{C}$ & & 103.0 & 108.5 & 108.2 & 108.7 \\
\hline $5, \mathrm{C}$ & & 160.8 & 156.6 & 156.6 & 156.7 \\
\hline $6, \mathrm{C}$ & & 111.2 & 117.5 & 117.4 & 117.3 \\
\hline $7, \mathrm{C}$ & & 153.8 & 159.7 & 160.5 & 159.5 \\
\hline $8, \mathrm{C}$ & & 112.3 & 116.6 & 115.8 & 116.1 \\
\hline $9, \mathrm{C}$ & & 145.4 & 147.5 & 147.5 & 147.0 \\
\hline $11, \mathrm{C}$ & & 78.2 & 78.4 & 78.3 & 79.2 \\
\hline $12, \mathrm{CH}_{2}$ & $\begin{array}{l}2.12, \mathrm{~m} \\
1.63, \mathrm{~m}\end{array}$ & 40.5 & 45.9 & 40.5 & 45.9 \\
\hline $13, \mathrm{CH}_{2} / \mathrm{CH}$ & $\begin{array}{l}1.84, \mathrm{~m} \\
1.52, \mathrm{~m}\end{array}$ & 22.6 & 70.1 & 22.6 & 72.2 \\
\hline $14, \mathrm{CH}$ & $1.55, \mathrm{~m}$ & 52.1 & 51.7 & 51.9 & 53.4 \\
\hline $15, \mathrm{C}$ & & 75.8 & 78.4 & 75.8 & 147.5, \\
\hline $17, \mathrm{C}$ & & 177.0 & 178.6 & 178.9 & 177.9 \\
\hline $18, \mathrm{CH}_{2}$ & $\begin{array}{l}2.32, \mathrm{~m} \\
2.61, \mathrm{~m}\end{array}$ & 30.1 & 30.5 & 30.3 & 30.0 \\
\hline $19, \mathrm{CH}_{2}$ & $\begin{array}{l}2.40, \mathrm{~m} \\
1.82, \mathrm{~m}\end{array}$ & 34.9 & 36.2 & 35.0 & 36.2 \\
\hline $20, C$ & & 42.8 & 42.1 & 42.8 & 40.7 \\
\hline $21, \mathrm{CH}$ & $1.68, \mathrm{~d}(8.2)$ & 41.5 & 41.5 & 41.4 & 40.7 \\
\hline $22, \mathrm{CH}_{2}$ & $\begin{array}{c}2.69, \mathrm{dd}(18.3,8.2) \\
2.94, \mathrm{~d}(18.3)\end{array}$ & 18.4 & 18.7 & 18.8 & 18.9 \\
\hline $23, \mathrm{CH}_{3}$ & $2.02, \mathrm{~s}$ & 10.6 & 10.8 & 10.6 & 10.8 \\
\hline $24, \mathrm{CH}_{3}$ & $1.21, \mathrm{~s}$ & 27.7 & 28.2 & 27.8 & 27.9 \\
\hline $25, \mathrm{CH}_{3} / \mathrm{CH}_{2}$ & $1.28, \mathrm{~s}$ & 33.2 & 32.1 & 33.2 & 116.1 \\
\hline $26, \mathrm{CH}_{3}$ & $1.21, \mathrm{~s}$ & 28.2 & 32.7 & 28.2 & 26.5 \\
\hline $27, \mathrm{CH}_{3}$ & $0.71, \mathrm{~s}$ & 19.4 & 18.5 & 19.6 & 20.9 \\
\hline $\mathrm{COOCH}_{3}$ & $3.67, \mathrm{~s}$ & 52.0 & 52.1 & & \\
\hline $5-\mathrm{OCH}_{3}$ & & & 62.3 & 62.2 & 62.3 \\
\hline
\end{tabular}


$3 \beta$-Hydroxy-agathic acid (9): colorless oil; $[\alpha]_{\mathrm{D}}^{25}+66(c 0.06, \mathrm{MeOH}) ; \mathrm{ECD}\left(c 5.7 \times 10^{-4} \mathrm{M}, \mathrm{MeOH}\right)$ $\lambda_{\max } 217$ (4.05); ${ }^{1} \mathrm{H}$ and ${ }^{13} \mathrm{C}$ NMR data, see Table 2; HRESIMS $\mathrm{m} / \mathrm{z} 373.1991[\mathrm{M}+\mathrm{Na}]^{+}$(calcd. for $\mathrm{C}_{20} \mathrm{H}_{30} \mathrm{O}_{5} \mathrm{Na}^{+}$, 373.1985).

Table 2. ${ }^{1} \mathrm{H}$ and ${ }^{13} \mathrm{C}$ NMR Data of 9 and $\mathbf{1 0}$ in Methanol- $d_{4}{ }^{a}$ ( $\delta$ in ppm).

\begin{tabular}{|c|c|c|c|c|}
\hline \multirow{2}{*}{ No. } & \multicolumn{2}{|l|}{9} & \multicolumn{2}{|l|}{10} \\
\hline & $\delta_{\mathrm{H}}($ mult., $J$ in $\mathrm{Hz})$ & $\delta_{C}$ & $\delta_{H}($ mult., $J$ in $\mathrm{Hz})$ & $\delta_{C}$ \\
\hline \multirow{2}{*}{$1, \mathrm{CH}_{2}$} & $1.24, \mathrm{~m}$ & \multirow{2}{*}{38.7} & $1.31, \mathrm{~m}$ & \multirow{2}{*}{38.1} \\
\hline & $1.91, \mathrm{~m}$ & & $1.93, \mathrm{~m}$ & \\
\hline \multirow{2}{*}{$2, \mathrm{CH}_{2}$} & $1.78, \mathrm{~m}$ & \multirow[t]{2}{*}{29.7} & $1.72, \mathrm{~m}$ & \multirow[t]{2}{*}{25.7} \\
\hline & $\begin{array}{l}2.16, \mathrm{~m} \\
318 \mathrm{dd}(121-4)\end{array}$ & & $\begin{array}{l}2.46, \mathrm{~m} \\
455 \mathrm{~d}(12345)\end{array}$ & \\
\hline $4, \mathrm{C}$ & $3.18, \mathrm{da}(12.1,4.4)$ & 50.3 & $4.53, \mathrm{au}(12.0,4.5)$ & 49.3 \\
\hline $5, \mathrm{CH}$ & $1.29, \mathrm{~m}$ & 56.5 & $1.43, \mathrm{dd}(12.8,2.4)$ & 56.6 \\
\hline \multirow{2}{*}{$6, \mathrm{CH}_{2}$} & $1.93, \mathrm{~m}$ & \multirow{2}{*}{27.2} & $1.63, \mathrm{~m}$ & \multirow{2}{*}{26.9} \\
\hline & $2.03, \mathrm{~m}$ & & $2.04, \mathrm{~m}$ & \\
\hline \multirow{2}{*}{$7, \mathrm{CH}_{2}$} & $1.93, \mathrm{~m}$ & \multirow{2}{*}{39.6} & $1.99, \mathrm{~m}$ & \multirow{2}{*}{39.3} \\
\hline & $2.42, \mathrm{~m}$ & & $2.43, \mathrm{~m}$ & \\
\hline $8, \mathrm{C}$ & & 149.0 & & 148.7 \\
\hline $9, \mathrm{CH}$ & $1.61, \mathrm{~m}$ & 56.5 & $1.65, \mathrm{~m}$ & 56.4 \\
\hline $10, \mathrm{C}$ & & 41.0 & & 40.8 \\
\hline \multirow{2}{*}{$11, \mathrm{CH}_{2}$} & $1.73, \mathrm{~m}$ & \multirow{2}{*}{23.0} & $1.75, \mathrm{~m}$ & \multirow{2}{*}{23.0} \\
\hline & $1.58, \mathrm{~m}$ & & $1.58, \mathrm{~m}$ & \\
\hline \multirow{2}{*}{$12, \mathrm{CH}_{2}$} & $2.02, \mathrm{~m}$ & \multirow{2}{*}{40.7} & $2.03, \mathrm{~m}$ & \multirow{2}{*}{40.6} \\
\hline & $2.30, \mathrm{~m}$ & & $2.30, \mathrm{~m}$ & \\
\hline $13, \mathrm{C}$ & \multirow{3}{*}{$5.61, \mathrm{~s}$} & 161.7 & & 161.2 \\
\hline $14, \mathrm{CH}$ & & 116.9 & $5.62, \mathrm{~s}$ & 115.8 \\
\hline $15, \mathrm{C}$ & & 170.4 & & 170.7 \\
\hline $16, \mathrm{CH}_{3}$ & $2.13, \mathrm{~d}(1.0)$ & 18.9 & $2.13, \mathrm{~s}$ & 18.9 \\
\hline $17, \mathrm{CH}_{2}$ & $\begin{array}{l}4.56, \text { br s } \\
4.90, \text { br s }\end{array}$ & 107.3 & $\begin{array}{l}4.57, \text { br s } \\
4.92 \text {, br s }\end{array}$ & 107.6 \\
\hline $18, \mathrm{CH}_{3}$ & $1.38, \mathrm{~s}$ & 24.8 & $1.24, \mathrm{~s}$ & 24.7 \\
\hline $19, \mathrm{C}$ & & 180.5 & & 177.5 \\
\hline $20, \mathrm{CH}_{3}$ & $0.69, \mathrm{~s}$ & 13.5 & $0.74, \mathrm{~s}$ & 13.1 \\
\hline $\mathrm{COCH}_{3}$ & & & $2.04, \mathrm{~s}$ & 21.1 \\
\hline$\underline{\mathrm{COC}} \overline{\mathrm{C}} \mathrm{H}_{3}$ & & & & 172.8 \\
\hline
\end{tabular}

$3 \beta$-Acetoxy-agathic acid (10): colorless oil; $[\alpha]_{\mathrm{D}}^{25}+58\left(\right.$ c 0.03, MeOH); ECD $\left(c 5.1 \times 10^{-4} \mathrm{M}, \mathrm{MeOH}\right)$ $\lambda_{\max } 225$ (3.78); ${ }^{1} \mathrm{H}$ and ${ }^{13} \mathrm{C}$ NMR data, see Table 2; HRESIMS $\mathrm{m} / z$ 415.2096 [M $\left.+\mathrm{Na}\right]^{+}$(calcd. for $\left.\mathrm{C}_{22} \mathrm{H}_{32} \mathrm{O}_{6} \mathrm{Na}^{+}, 415.2091\right)$.

\section{5. $\alpha$-Glucosidase Assay}

The $\alpha$-glucosidase inhibitory effect was assessed as follows. First, $0.2 \mathrm{U}$ of $\alpha$-glucosidase from Saccharomyces cerevisiae was purchased from Sigma-Aldrich (St. Louis, MO, USA), and was diluted in a $0.067 \mathrm{M}$ phosphate buffer consisting of $\mathrm{Na}_{2} \mathrm{HPO}_{4} \cdot 12 \mathrm{H}_{2} \mathrm{O}$ and $\mathrm{KH}_{2} \mathrm{PO}_{4}(\mathrm{pH}$ 6.8). The assay was conducted in a $60 \mu \mathrm{L}$ reaction system containing $20 \mu \mathrm{L}$ of diluted enzyme solution, and $20 \mu \mathrm{L}$ of dimethyl sulfoxide (DMSO) or sample (dissolved in DMSO). After $10 \mathrm{~min}$ of incubation in 96-well plates at $37^{\circ} \mathrm{C}$, a $20 \mu \mathrm{L}$ portion of $4 \mathrm{mM}$ 4-nitrophenyl- $\alpha$-D-glucopyranoside (PNPG) (Aladdin, Shanghai, China) was added as a substrate to start the enzymatic reaction. The plate was incubated for an additional $20 \mathrm{~min}$ at $37^{\circ} \mathrm{C}$, and the reaction was quenched by adding $60 \mu \mathrm{L}$ of $0.2 \mathrm{M} \mathrm{Na}_{2} \mathrm{CO}_{3}$. The final concentrations of tested compounds were between 0.2 and $2 \mathrm{mM}$. The optical density (OD) was measured at an absorbance wavelength of $405 \mathrm{~nm}$ using a Microplate Reader (Tecan, Mannedorf, 
Switzerland). All assays were performed in three replicates, and acarbose (Aladdin, Shanghai, China) was used as the positive control.

\section{Conclusions}

In conclusion, a new austalide meroterpenoid (1) and seven known austalide analogues (2-8), two new labdane-type diterpenes (9 and 10) and one known derivative (11) were isolated from a fraction of the EtOAc extract of the deep-sea derived strain Penicillium thomii YPGA3. The structures of compounds 1, 9, and $\mathbf{1 0}$ were determined by comprehensive analyses of the NMR and mass spectroscopy (MS) data, the absolute configurations of $\mathbf{1}$ and $\mathbf{9}$ were determined by ECD calculations. Compound 1 showed weak inhibition toward MDA-MB-468 cells with an $\mathrm{IC}_{50}$ value of $38.9 \mu \mathrm{M}$. Compounds $\mathbf{2}$ and $\mathbf{1 1}$ exhibited inhibitory effects against $\alpha$-glucosidase with $\mathrm{IC}_{50}$ values of 910 and 525 $\mu \mathrm{M}$, respectively, being more active than the positive control acarbose $(1.33 \mathrm{mM})$.

Supplementary Materials: The following are available online at http://www.mdpi.com/1660-3397/18/3/164/s1, Figures S1-S37: ${ }^{1} \mathrm{H},{ }^{13} \mathrm{C}$ NMR, HSQC, ${ }^{1} \mathrm{H}-{ }^{1} \mathrm{H}$ COSY, HMBC, HRESIMS spectra of the new compounds 1, 9, and 10, ${ }^{1} \mathrm{H}$ and ${ }^{13} \mathrm{C}$ NMR of known compounds 2-8, and 11, and details for ECD calculations.

Author Contributions: Z.C., W.L., Y.L., and S.H. isolated the compounds and elucidated the structures. W.L., X.C., and J.Z. tested the inhibition against $\alpha$-glucosidase. R.F., Y.W., and Y.Z. tested the inhibition against LPS-induced NO production in RAW 264.7 macrophage cells. R.F. conducted the MTT assay. X.L., S.A.A., W.X., and Z.L. isolated and identified the fungus, and conducted the solid fermentation of the fungus. Z.C. and Q.L. designed the study and edited the manuscript. All authors have read and agreed to the published version of the manuscript.

Funding: This work was supported by grants from the National Natural Science Foundation of China (81903536), the National Key R\&D Program of China (2017YFD0600702-2), the China Ocean Mineral Resources R\&D Association Program (DY135-B2-01 and DY135-B2-09), the Youth Talent Promotion Project of Henan Province (2020HYTP059), the First-Class Discipline Construction Project of Henan University (2018YLZDCG03), China-ASEAN Maritime Cooperation Fund Project "Monitoring and conservation of the coastal ecosystem in the South China Sea", and Bilateral Cooperation of Maritime Affairs.

Acknowledgments: The authors thank Jianxun Kang at Zhengzhou University for NMR measurements.

Conflicts of Interest: The authors declare no conflict of interest.

\section{References}

1. de Jesus, A.E.; Horak, R.M.; Steyn, P.S.; Vleggaar, R. Biosynthesis of austalide D, a meroterpenoid mycotoxin from Aspergillus ustus. J. Chem. Soc. Chem. Commun. 1983, 13, 716-718. [CrossRef]

2. Horak, R.M.; Steyn, P.S.; Van Rooyen, P.H.; Vleggaar, R.; Rabie, C.J. Structures of the austalides A-E, five noval toxic metabolites from Aspergillus ustus. J. Chem. Soc. Chem. Commun. 1981, 24, 1265-1267. [CrossRef]

3. Horak, R.M.; Steyn, P.S.; Vleggaar, R.; Rabie, C.J. Metabolites of Aspergillus ustus. Part 1. A of the heteronuclear selective population inversion (SPI) n.m.r. technique to the structure elucidation of the austalides A-F, novel ortho ester meroterpenoids. J. Chem. Soc.-Perkin Trans. 1 1985, 345-356. [CrossRef]

4. Horak, R.M.; Steyn, P.S.; Vleggaar, R. Metabolites of Aspergillus ustus. Part 2. Stereoelectronic control in the acid-catalysed hydrolysis of the ortho ester moiety in austalides A-F. J. Chem. Soc.-Perkin Trans. 1 1985, 357-361. [CrossRef]

5. Horak, R.M.; Steyn, P.S.; Vleggaar, R.; Rabie, C.J. Metabolites of Aspergillus ustus. Part 3. Structure elucidation of austalides G-L. J. Chem. Soc.-Perkin Trans. 1 1985, 363-367. [CrossRef]

6. Zhou, Y.; Mándi, A.; Debbab, A.; Wray, V.; Schulz, B.; Müller, W.E.G.; Lin, W.; Proksch, P.; Kurtán, T.; Aly, A.H. New austalides from the sponge-associated fungus Aspergillus sp. Eur. J. Org. Chem. 2011, 2011, 6009-6019. [CrossRef]

7. Zhou, Y.; Debbab, A.; Wray, V.; Lin, W.; Schulz, B.; Trepos, R.; Pile, C.; Hellio, C.; Proksch, P.; Aly, A.H. Marine bacterial inhibitors from the sponge-derived fungus Aspergillus sp. Tetrahedron Lett. 2014, 55, 2789-2792. [CrossRef]

8. Peng, J.; Zhang, X.; Wang, W.; Zhu, T.; Gu, Q.; Li, D. Austalides S-U, New meroterpenoids from the sponge-derived fungus Aspergillus aureolatus HDN14-107. Mar. Drugs 2016, 14, 131. [CrossRef] [PubMed]

9. Zhuravleva, O.I.; Sobolevskaya, M.P.; Leshchenko, E.V.; Kirichuk, N.N.; Denisenko, V.A.; Dmitrenok, P.S.; Dyshlovoy, S.A.; Zakharenko, A.M.; Kim, N.Y.; Afiyatullov, S.S. Meroterpenoids from the alga-derived fungi 
Penicillium thomii Maire and Penicillium lividum Westling. J. Nat. Prod. 2014, 77, 1390-1395. [CrossRef] [PubMed]

10. Antipova, T.V.; Zaitsev, K.V.; Oprunenko, Y.F.; Zherebker, A.Y.; Rystsov, G.K.; Zemskova, M.Y.; Zhelifonova, V.P.; Ivanushkina, N.E.; Kozlovsky, A.G. Austalides V and W, new meroterpenoids from the fungus Aspergillus ustus and their antitumor activities. Bioorg. Med. Chem. Lett. 2019, 29, 126708. [CrossRef] [PubMed]

11. Wang, W.; Lee, J.; Kim, K.-J.; Sung, Y.; Park, K.-H.; Oh, E.; Park, C.; Son, Y.-J.; Kang, H. Austalides, osteoclast differentiation inhibitors from a marine-derived strain of the fungus Penicillium rudallense. J. Nat. Prod. 2019, 82, 3083-3088. [CrossRef] [PubMed]

12. Cheng, Z.; Xu, W.; Wang, Y.; Bai, S.; Liu, L.; Luo, Z.; Yuan, W.; Li, Q. Two new meroterpenoids and two new monoterpenoids from the deep sea-derived fungus Penicillium sp. YPGA11. Fitoterapia 2019, 133, 120-124. [CrossRef] [PubMed]

13. Cheng, Z.; Li, Y.; Xu, W.; Liu, W.; Liu, L.; Zhu, D.; Kang, Y.; Luo, Z.; Li, Q. Three new cyclopiane-type diterpenes from a deep-sea derived fungus Penicillium sp. YPGA11 and their effects against human esophageal carcinoma cells. Bioorganic Chem. 2019, 91, 103129. [CrossRef] [PubMed]

14. Cheng, Z.; Li, Y.; Liu, W.; Liu, L.; Liu, J.; Yuan, W.; Luo, Z.; Xu, W.; Li, Q. Butenolide Derivatives with $\alpha$-glucosidase inhibitions from the deep-sea-derived fungus Aspergillus terreus YPGA10. Mar. Drugs 2019, 17, 332. [CrossRef] [PubMed]

15. Cheng, Z.; Xu, W.; Liu, L.; Li, S.; Yuan, W.; Luo, Z.; Zhang, J.; Cheng, Y.; Li, Q. Peniginsengins B-E, New farnesylcyclohexenones from the deep sea-derived fungus Penicillium sp. YPGA11. Mar. Drugs 2018, 16, 358. [CrossRef] [PubMed]

16. Jim-Min, F.; Yi-Chien, S.; Yu-Hung, C.; Yu-Shia, C. Diterpenes from the bark of Juniperus chinensis. Phytochemistry 1993, 34, 1581-1584. [CrossRef]

17. Kiren, Y.; Nugroho, A.E.; Hirasawa, Y.; Shirota, O.; Bekenova, M.; Narbekovich, N.O.; Shapilova, M.; Maeno, H.; Morita, H. Mumic acids A-E: New diterpenoids from mumiyo. J. Nat. Med. 2014, 68, 199-205. [CrossRef] [PubMed] 